УДК 330.322(479.22)

\title{
INVESTMENT ENVIRONMENT OF GEORGIA AND WAYS OF ITS DEVELOPMENT
}

\author{
Katamadze D. Sh.
}

Анотація. Методологічна основа дослідження статті є комплексним підходом, який дозволив встановити властиві інвестиційному середовищу перешкоди та фактори залучення інвестицій. У процесі дослідження були використані методи абстракції, індукції та дедукції, узагальнення статистичних даних, групування, аналізу і синтезу. Дослідження показали, що в Грузії основними чинниками, які перешкоджають вдосконаленню інвестиційного середовища, $\epsilon$ : напружена політична обстановка в стосунках з Росією, політично-економічна нестабільність, низька ємність місцевого ринку споживачів у валютному, кредитному, інвестиційному, фінансовому секторах. Після виявлення головних перешкод і факторів вдосконалення інвестиційного клімату, можна намітити відповідні заходи для усунення негативних впливів: 3 метою формування привабливого інвестиційного клімату необхідно спочатку обробити і провести короткострокові заходи, що мають негайний ефект, зокрема: зниження адміністративно-бюрократичного бар'єру; ефективний захист прав власності і створення рівноправних умов господарсько-економічної діяльності; підвищення публічності економічних процесів і їх результатів. Ці проблеми можуть вирішуватися порівняно легше і з меншими витратами, оскільки вони залежать від політичної волі прийняття законодавчих актів.

Надалі слід розробити і реалізувати такі заходи довгострокового ефекту, як: впровадження принципів економічної демократії, внесення радикальних змін в економічному базисі, радикальне перетворення свідомості населення, економічне виховання нації тощо, реалізація чого вимагає більшого часу, матеріальних, трудових і фінансових витрат.

Ключові слова: інвестиційне середовище, іноземні інвестиції, підвищення публічності економічних процесів.

Аннотация. Методологическая основа исследования статьи представляет комплексный подход, который позволил установить свойственные инвестиционной среде факторы привлечения инвестиций, а также препятствия. В процессе исследования были использованы методы абстракции, индукции и дедукции, обобщения статистических данных, группирования, анализа и синтеза. Исследования показали, что в Грузии основными факторами, препятствующими совершенствованию инвестиционной среды, являются: напряженная политическая обстановка в отношениях с Россией, политико-экономическая нестабильность, низкая емкость местного рынка потребителей в валютном, кредитном, инвестиционном, финансовом секторах.

После выявления главных препятствий и факторов совершенствования инвестиционного климата, можно наметить соответствующие мероприятия для устранения негативных воздействий: с целью формирования привлекательного инвестиционного климата необходимо сначала обработать и провести краткосрочные меры, имеющие немедленный эффект, как снижение административно-бюрократического барьера; эффективная защита прав собственности и их создания равноправных условии хозяйственно-экономической деятельности; повышение публичности экономических процессов и их результатов. Эти проблемы могут решаться сравнительно легче и гораздо с меньшими затратами, поскольку они зависят от политической воли принятия законодательных актов.

В дальнейшем надо выработать и провести такие меры долгосрочного эффекта, как: внедрение принципов экономической демократии, внесение радикальных изменений в экономическом базисе, радикальное преобразование сознания населения, экономическое воспитание нации и т. д., реализация чего требует большего времени, материальных, трудовых и финансовых затрат. Ключевые слова: инвестиционная среда, иностранные инвестиции, повышение публичности экономических процессов. 
The problem's setting. The survey revealed that the main obstacle to improve the investment environment in Georgia are the following factors: tense political situation with Russia, political and economic instability, the local consumer market low-capacity, low level of purchasing power of the population. The aforementioned factors would be found in: foreign exchange, credit and investment, the financial sector.

The functioning of the business complex of the country is impossible without investments. So for the country performing investments import is important to estimate the investment environment. All these actions are vital to analyze how the situation is favorable for the investor for capital investment. When an investor assesses the situation multilaterally, the possibility of capital investment as ideological, as well as political and, most importantly, in economic terms, it analyzes all factors needed for investment efficiency and determines investment risk. As it is known, the foreign capital flow significantly contributes to the mitigation of the economic crisis, raises living standards and reduces unemployment. It allows without state debt magnification to achieve economic growth.

The subject of the article. The article investigates the investment environment of Georgia.

The aim of the article. The purpose of the article is to determine factors that have the influence on Georgian investment environment.

The article methodology (methods). The methodological basis of the article was grounded on comprehensive approach as well as characteristics of the investment environment and possible attraction of foreign investment and determining main factors. The article was based on different methods: abstraction, induction and deduction, statistical generalization, aggregation, grouping, analysis and synthesis methods.
The main results and its grounding. The investment environment characterizes public living conditions in all the areas which are closely interconnected factors influencing investment (for the investor and investment recipient party - it will be a country, region, city, district, village or firm) becomes attractive or unfavorable. Investment environment, according to its specific, cannot quickly improve. Up to present time in none of the countries took place such a case, when one of the important state act, law (or even a combination of laws) suddenly, dramatically changed the business "climate".

Investment environment is formed gradually, in the process specific for market relations characterizing institutions establishment and evolutional development process, while increasing positive expectations of investors and debtors. In this sense, our country still has many problems to be solved:

There aren't established stock exchanges, intermediary institutions, securities market is in drawing condition, limited investment portfolio formation, review and evaluation capabilities. Because of aforementioned, in near-term outlook in Georgia real sector large, potential investment attraction and investment is still limited.

Georgian economic development modern situation analysis shows that the country's investment climate, despite measures taken, is less attractive for foreigners as well as local investors. There are many reasons, their study, identify eliminating ways and investment efficiency development is given great importance.

In our country, the current economic potential full operation requires relevant financial support. Economy financing Internal resources are scarce, because of populations financial activity limitation. As a result of inequality of income distribution, a large part of the material wealth is concentrated in a small group of the populations. They spend the income for personal use, investing overseas or in domestic market with high profit statutory 
monopoly sectors. Economy reduced reproduction and GEL exchange rate maintenance attempt, strict monetary and credit policy implementation cannot provide solid financial base for the domestic investment.

Therefore, according to real situation in our country the real way for local production funding is foreign investment attraction. Foreign investment is the country's macroeconomic stabilization one of the efficient instruments. In 2008-2016 firstly Georgia-Russia relations, and then our dues to domestic political situation tension has increased investment risk, which prevents public access to the necessary production bottlenecks enough volume to attract investment, but foreign investment attraction drawback is that in the long-term period previously invested capital, as a rate revenues, earned income large part is deducted from the economic growth rates, and sooner or later flows abroad, but, in the modern world market saturation conditions, an investor in the company's sales network, their trade mark usage right to use and the accompanying technological effect is so great that it overrides the losses suffered from leakage.

For the illustration of foreign investment acceptable income and lose can be considered in recent years in Georgia attracted foreign direct investment volume, origin and structural sector.

Foreign direct investments volume in 2016 reaches 1645 million US dollars, which is $22 \%$ higher than 2015 preliminary and by $5 \%$ - revised data. At the same time reinvesting volume amounted direct foreign investment total volume $32 \%$ (Source: www.geostat.ge. National Statistical Office of Georgia. Foreign direct investment).

In 2016, according to director foreign investment in Georgia among the largest investor countries three largest investor country share according to 2016 data, amounted 59\%. According to investment by foreigners we can conclude that Azerbaijan took the first place - by $35 \%$, the second $17 \%$, Turkey, the third - the United Kingdom $7 \%$ (Source: www.geostat.ge. National Statistics Office of Georgia. Foreign direct investment according to countries).

In 2016, the total amount of investment in Georgia was 39\%. It came to transport and communication, energy $-12 \%$, the financial sector $-8 \%$, processing industry $-7 \%$, hotels and restaurants $-7 \%$, real estate $-4 \%$, while on other sectors only $12 \%$ came (Source: www.geostat.ge. National Statistics Office of Georgia. Foreign direct investment according to economic sectors).

It should also be indicated that chaotic influx of foreign investment is not justified, because it is dangerous and foreigners take control over strategically important sectors. At that time to be considered conducting negotiations with foreign investors. This is due to the fact that after investors coming it becomes difficult to control their activities, in the local market gradually suppressed competition, non-renewable natural and industrial recourses (materials) go under foreign investors control. As a result, our country's resources are wasted and prematurely exhausted. In the conditions of absence of institutional systems and the existence of a weak state administration there doesn't exist strict environmental controls guarantees for foreign direct investment basis on launched enterprises activities [1, p. 404].

Investment deficiency results labor low productivity and decrease in investment incentives. Attraction of foreign investments in Georgia hinders unfavorable investment climate: frequently changing tax system, high levels of bureaucracy [4, p. 517], the risk of future uncertainty, Foreign investment regulating legislative base frequent changes, stock market, securities market underdevelopment, investment insurance low level, tense political situation, low purchasing level, oligopoly high level, technological lag and unresolved relationship with Russia.

Especially the last factor foreign 
investment attracting hindering main reason in Georgia, because "Business does not like being there, where the gun's thunder". Therefore, intense political situation our country's government is busy by pursuing only economic reforms. Still is not developed targeted state investment policy. It is important to offer foreign investors profitable investment projects and favorable investment proposals. Researchers during studying Georgian investment market declare that there are small business activity growth prospects. Still it is not perfect investment processes state management and insurance (collateral funds formation) unified mechanism, but there is the possibility of reducing production costs, automobile and railway line, energy investment prospect.

Recently foreign investments volume in tourism, construction and energy sectors has increased. During the cooperation with foreign investors, it is necessary to present and protect national interests. Foreign investors are a strategic asset-seeking group, which is a threat to our country. So we should encourage such investments, which will be focused on exploring new territories, time-consuming industries and funding of high unemployment regions.

Accordingly, it is necessary the government take cautious investment policy when attracting foreign investment. Great attention should be paid to issues of sovereignty, implying foreign investment including country's interests. At the present stage, Georgian economy is completely dependent on external economic factors. To overcome this problem, it is required technological cooperation with foreign firms, establishment of joint enterprises, the sale of shares to foreign investors, cooperation on the basis of the agreements and creating new enterprises by foreign investors.

At the present stage worldwide between countries and continents ongoing barter process is featured with the following peculiarity, that with advanced technique equipped largest companies that are potential investors, virtually exhausted the possibility of capital growth through exports or even within the country, due to local market saturation. Therefore, these companies are being forced to change their actions in the battle for new markets and the expansion of commodity strategy to shift away from the strategy of capital withdrawal. Under these conditions, Georgia, which is suffering from lack of investment, in sectoral or regional context, in case of financial support is going to be a good investment market.

In Georgia for investment attraction a great importance is given to political forces the world re-distribution and by highly developed countries takes an interest in our country, which creates its territorial, political stability and socio-economic security. All these investments are condition for wide entry. Our country's investment activities established trends suggest that many Western investors are often investment destination in the country's political stability. It is seen as a more attractive environment than the other conditions.

Georgia is actively involved in international and regional associations. It is the World Trade Organization, the United Nations and the European Union associate member country. Our country's aspiration is to join the EU and NATO. It is GUAM countries regional association initiator; it is widely involved in the TRACECA and BSEC countries joint projects, etc. The United Nations created friendly countries group of Georgia. All this increases the authority of our country in the world, which is the guarantee for investors for the implementation of more profitable activities in Georgia.

Investment environment development essential factor is liberalization of the economic system, its arrangement in the manner, which will be directed towards the investment acceleration, investment incentives growth, which is eventually reflected in manifestation of the principles of economic democracy. 
Investment environment development important factor is budget-tax system perfection, tax and custom goods alleviation to the manufacturer, creating such a conditions, that will strengthen their scientific and technical base development basis.

While many reforms have been carried out in the legislative terms, budget-tax system is still a favorable investment climate formation biggest brake. This is the case when the country has laws, there are made frequent changes (only in the tax code, from its receipt up to today, more than two thousand changes were made), but they cannot give incentives to foreign investment attraction, because the laws do not describe the Georgian reality, cannot meet the conversion modern requirements.

In order to do the direction of Budget-tax burden easing, the first steps should be taken to the value added tax (hereinafter VAT) high rates reducing, their optimization, because, according to its essence, the VAT is taxation of over normative profit tax, it contributes development of the sector, in which there is excessive profit gained, and others stagnation or even bankruptcy. It should be introduced VAT payment such a sectoral differentiation, which created for Georgian enterprises additional funds for investments.

If after VAT payment by enterprise carried out investment profitability falls below the sectoral level (15\%), then he/she should not be charged VAT total amount. This should apply especially to those enterprises, which use the latest techniques and technology. In Other sectors VAT payment basis should be fixed capital residual value (depreciation) profitability, which shouldn't go lower than $12 \%$. The foregoing measures, in our opinion technical equipment low level enterprises should bring motivation to actively update the basic funds and outpace technologically advanced enterprises.

Investment implementation process will also accelerate even it if companies won't be levied the part of the profit, which should be used to purchase new production facilities, for modernization and technical improvement of the existing ones. If we look at the issued with broader aspect, we will consider the tax burden, as the budget financial load whole system consistent part. Thus, its mitigation must be connected to each other arrangements, not only the taxes and tolls of various types, but all part of the financial burden - export and import customs duties on goods, natural monopolies production prices, import tariffs, dividends, depreciation norms, washing Investment remuneration terms, exchange rates and etc.

In addition, to alleviate the financial burden can be made by imposing the investors tax benefits general or selective, budgetary subsidies and donations giving to priority industries and depressed regions, as well as the investment activities priority projects. The same purpose serve by state budget redistribution, the regulatory function performance (by natural monopolists manufactured goods and services prices and tariffs regulation, as well as foreign economic relations, carrying out other protectionist policies). Since took place investment financial decentralization, the state is obliged to ensure that investments from other sources for the farming conditions in which enterprises will be able by their activity to create financial funds.

In this regard, when carrying out states regulatory function one of the most important problems is to prevent monopoly enterprises product (service) price increases, and thus an increase in costs. Solving of this issue will help enterprises to create additional sources of accumulation. At the same time, by taking financial burden alleviating measures, legislators should take into account that neither taxes nor increase enormously reduction would not contribute to speeding up the process.

Investment activity in Georgia is especially at the lower level in the regions, due to tax revenues are overly centralized and for on-site expanded reproduction nothing is left, which to the functioning business entities restricts revenues and investment carrying out 
possibility from the local budget.

Therefore, it is necessary for the regions to introduce differentiated tax and customs exemptions, in the regions tax revenues more part to be left on the place $(50-60 \%)$ and to be charged with differentiated tax and customs benefits. In Georgia only for two or three regions taxes (including customs) received funds distribution standards establishments deepens socio-economic development distortions and, therefore, will not contribute to the activation of investment activity. So tax and customs revenues long-term provision rates establishment practice should be extended to all (especially depression) regions, which will contribute the region's economic situation strengthening and activation of investment activity.

Country's credit policy requires perfections, which primarily should be directed to the on loans spread towards the direction of liberalization of current interest rate. Special attention should be given to the liberalization of interest rates on loans to the regional level, the country's most promising economic development and priority investment projects. The priority in Business and economic activity should be given to long-term credit system introduction widely. Investment attraction stimulating role performance is impossible without strict control over investments, credits and grants adoption and without respecting mutual accountability.

The government, and all citizens must be aware where and how investment funds have been spent and what results were obtained. Investment activity economic results transparency is investment inflow further expansion important factor. It is necessary regions actively get involved in investment cooperation with other countries. Regions, should have they representatives in other countries and should have right without interference of central government to establish direct investment contacts with partner countries, conclude contract with them, that they were themselves investment protection guarantee and ensure investment in highefficiency, and the result received use for the revival of the regions.

Of course, there should be taken into consideration the condition, that according to pre adopted standards from the received revenues some part send to central budget. Together with political factors the most significant economic mechanism for investor country nationals giving legal support for staying in the country for indefinite period of time with the less expenses, introduction of special liberal regime for their relocation. The most relevant investment activity quantitative and relative rates accounting reports and statistical accounting, audit unifying system establishment, which will be adapted to international standards.

Parallel to the tax load optimization we should enhance tax system flexibility, its compensation, redistribution and stimulating functions. Without it we cannot expect development of the investment environment and acceleration of innovation processes. In Georgia should be given a large-scale to the development of investment activities, such as leasing. Economically for Low economic development level of our country, which lacks its own financial means, leasing of vehicles, equipment, machinery, automation and for the introduction of scientific and technological advances is the most effective way.

Currently in the low development conditions of the country and regions, when the regions differ dramatically from one another in investment activity level, for the investor should be established tax, customs and other benefits for the regions, which are investing their capital in depressed, backward regions, benefits differentiation should be made according depression quality in accordance with regions ranks.

As well as business and economic benefits should be applied to the less efficient sectors investment. Georgia's acute economic, political, social, ecological and demographic crises reduce investment attractiveness. On our 
country's investment environment has negative impact "from Soviet-era inherited" deformed economy, due to which in Georgia was not formed complete mechanism for savings transformation into investments. Accordingly, our country's enterprises work in investment funds deficiency conditions.

The investment environment one of the major hindering factors is social consensus no existence on investment development processes. It is unfortunate that part of Georgian population is against attraction of foreign investment, and they consider it as the people's "enslavement" tool. It is obvious that in the democracy conditions no one can impose on society virtue of an outright investment, but it is important to assure them in investment goodness, the fact that the investments can have a positive impact on their living standards. The country's investment environment affecting the foreign debt, but surprisingly it can still be considered as a means of attracting additional investment.

After achieving national independence, Georgia's investment environment development one of the most important factor became its geopolitical situation. It is considered as a means of attracting investment. Georgia's investment attractiveness depends on scientific and technical progress achieved application level, as well as within the country's financialeconomic and political system, and the degree of independence and other. It is our country's political and economic security achieving means, which does not belong to any particular economic entity, but if Georgia receives foreign investment with a particular region, district, city, town, village or community support, then the latter should be given their territory, "the location rent".

Investment activity activation prerequisite in Georgia can be transformed through Georgia oil and gas pipelines operation, but the government shouldn't rely to pipelines related investment. This largescale projects need to turn into our country's investment stability guarantee, in other sectors direct foreign investment attraction and innovative process acceleration one of the most important prerequisites. "Transcaucasia Corridor: Europe-Caucasus-Asia" plays favorable role in Georgia's investment climate formation process. Thus, at the current stage real condition are created to use in our favor Georgia's geopolitical location, it creates a wide scope for foreign direct investments attraction in all areas of public lives.

Thus, in the internal market of local capital "fasten" and its optimal combination with foreign investments should be ensured economic growth high pace. Foreign investment attraction will contribute agreement concluded between Georgia and European Union Association and visa-free travel right within the Schengen zone. European Union high solvent market interested investors in order to reduce business costs, expressed its interest by European Union proposed cooperation regime and will try to manufacture products in Georgia. Because of our country's labor resources cheapness, they will try to bring into Georgia raw materials, capital, technology, manufacturing details, semi-finished products, in order to produces them in our country. It will attract investment and will increase working places in Georgia [3, p. 418].

Conclusions and further prospects of the research. Thus, as can be seen from the aforementioned analysis, in order to improve the investment environment of Georgia, it is necessary to:

1. First quick impact measures should be developed in a short-term period:

a) as well as the need to immediately reduce the bureaucratic barriers;

b) also it should be adhered the assets holders' property rights;

c) we also need to create equal conditions for investors;

d) investment and financial processes publicity level should be increased;

2 . Besides the quick impact recommendations, for our country's investment 
environment development measures of longterm effect should be elaborated:

a) it is necessary to fully implement the principles of democracy;

b) the need to enter in the base of the radical economic changes;

c) also to be converted the consciousness of the population, should be turned to the new reality, should be given to the nation economic education; d) at the same time it is necessary to deal with conflict situation with Russia, and within the country to be achieved political stability;

e) in addition, tax system should become transparent, stable;

f) should be attracted new technology and develop competition;

g) foreign investment insurance system should enter into force;

h) also the formation of the securities market is needed to speed up.

\section{References}

1. Baratashvili, E. and Magrakvelidze, D. (2009), Investment Environment Development Principles in Georgia, Tbilisi, Georgia.

2. Sichinava, A. (2010), Investments, Tbilisi, Georgia.

3. Kokiauri, L. and Bebiashvili, N. (2009), Investment Projects: Theory, Analysis, Management, TSU, Tbilisi, Georgia.

4. Gigiashvili, O., Futkaradze, R., Tholordava, G. et al. (2011), International business, Publishing house "Universali", Tbilisi, Georgia.

5. Official site of National statistical service materials of Georgia, [Online], available at: http://www.geostat.ge (Accessed 18 May 2017).

\section{Бібліографічний опис для циитування:}

Katamadze, D. Sh. Investment environment of Georgia and ways of its development / D. Sh. Katamadze // Науковий журнал «Економічні горизонти». - 2017. - № 1(2). - C. 4-11. 